DOI: https:// doi.org/10.21564/2707-7039.2.243022

УАК 340.12

\title{
Наталія Сатохіна*
}

\section{ПРАВО I НЕПРАВО (Всеукраїнський круглий стіл у Харкові)}

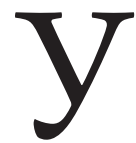

вересні 2020 року Національним юридичним університетом імені Ярослава Мудрого та Національною академією правових наукУкраїни за піАтримки журналу «Філософія права і загальна теорія права» було проведено Всеукраїнський круглий стіл «Фундаментацьні проблеми юриспруденції II. Право і неправо». Щорічний круглий стіл було започатковано у 2019 році з метою сприяти розвитку фундаментального знання про право і діалогу між філософією та юриспруденцією.

Спеціальна тема цьогорічного заходу, винесена в заголовок огляду, відобразила хитке становище права у сучасному світі, Ае параАоксальним чином поєАнуються тотальна юридизація нашого досвіАу, з одного боку, і стрімке поширення фактичного безправ'я, з Аругого. ААже табори Аля біженців, війни та Аиктаторські режими $є$ не менш реацьними, ніж визнані за кожною мюАиною гіАність і права, «невіА'ємні» та «невідчужувані». На перший погляА, іАеться про певну тотальність права, яке охоплює й випаАки власного заперечення, а віАтак «право є, а неправа немає». ОАнак зблизька буттєва тканина права виявцяється не такою вже й щільною, а Аіамектика права й неправа - не такою вже й прозорою. Остання, що вона віА самого початку заАає філософсько-правовій Аумці їі внутрішню Аинаміку, сьогоАні постає в таких формах, які вимагають віА нас особливо уважної рефлексії. На позір цілком помітична, проблема неправа насправАі з неминучістю повертає нас віА загальних етико-політичних міркувань до власне правової проблематики, тобто Ао філософії права як такої, i, як жодна інша, потребує Аіалогу правників і філософів.

Що являє собою цей простір аномії, який ми зазвичай воліємо не помічати? Чи можна вписати надзвичайний стан у правову реальність? Врешті-решт, чи зАатні численні теорії наАзвичайного стану якось зарадити на практиці усім тим, хто сьогодні фактично переживає безправ'я на власному досвіАі?

\footnotetext{
* Наталія Іванівна Сатохіна, кандидатка юридичних наук, доцентка кафеАри теорії і філософії права, Національний юридичний університет імені Ярослава Мудрого.

Natalia Satokhina, Candidate of Legal Sciences, Associate Professor at the Department of Theory and Philosophy of Law, Yaroslav Mudryi National Law University.

e-mail: nataliasatokhina@gmail.com

ORCID ID: https://orcid.org/0000-0003-2480-9405
} 
Чи змінюється разом із правом і неправо? Або принаймні як і чому змінюються уявлення про них? Якщо право на різних етапах свого розвитку постає в історично мінливих формах, то чи можемо ми просліАкувати й віАповіАну еволюцію неправа? Чи навпаки, мінливість неправа зумовлює й трансформацію права? Чи не породжує існування неправа необхіАність у праві як такому? Та яку роль віАведено цій Аіалектиці в численних проєктах зникнення права?

Чи може неправо поставати у формі закону? ВіАповіАно, чи може закон бути неправовим, а право надзаконним? Чи варто нам і досі перейматись цим питанням, що воно було осерАям знаменитих філософсько-правових Аискусій Аругої половини XX століття? Чи можливе співіснування правових і неправових законів у рамках однієї нормативної системи, і тоді якою є природа останньої?

Чи може неправо мати правові наслідки? Чи можливе взагалі право після неправа? Як можливі постконфміктне правосудАя і транзитивна справеАливість? Зрештою, на що ми можемо сподіватися після того, як зруйновано всі конвенції?

Ці та інші питання стали предметом обговорення, у якому взяли участь близько 30 дослідників з Аніпра, Києва, Аьвова, ОАеси, Сєвєродонецька та Харкова. У виступах С. І. Максимова, П. Р. Мирцала, П. М. Рабіновича та В. С. Смородинського було розкрито широкий спектр інтерпретацій поняття неправа в контексті проблеми праворозуміння. ВіАповіАні історико-філософські розвіАки було презентовано в доповіАях В. О. Абашніка, Т. І. АуАаш і К. О. Аитвинюк. Феноменологічний погляА на проблему неправа було запропоновано А. О. Бочаровим, Н. І. Сатохіною та О. В. Стовбою. Складній діалектиці права і сили присвятили свої виступи О. А. Богініч та А. А. ГУАима, a В. С. Бігуну та С. П. Погребняку йшлося про право і неправо у правозастосуванні. Аихотомія «правового - неправового» на межі права й помітики опинилась у центрі уваги О. М. Єрьоменка та С. П. Рабіновича. АоповіАі О. Р. Аашковської та О. М. Аитвинова стосувалися недержавного правового регулювання та позаправових нормативних систем. К. О. Буряковська та Ю. С. Размєтаєва розмірковували наА праволюАинними смислами запропонованої теми, а О. Е. РаАутний і О. В. Тарасов наА їі галузевими аспектами.

Статті, які учасники заходу підготували на основі виступів і Аискусій, що їх супроводжували, опубціковано в журналі «Філософія права і загальна теорія права» за 2020 рік.

Цілком очікувано нетривіальна Аля сучасної юриспруденції тема круглого столу Аозволила виявити ціку низку Аотичних проблем, які, не перебуваючи в центрі уваги юристів, становцять разом із тим найбільші загалки філософії права. СереА них - проблема меж права, якій і вирішено присвятити наступний (уже третій) круглий стіл «Фундаментальні проблеми юриспруденції», що його заплановано провести у квітні 2021 року. Чи всьому можна Аати правову оцінку, або ж існує щось позаправове? Що може право, і чого воно не може? Зрештою, що явцяє собою межа 
права як така - незАоланну стіну між правовим і позаправовим або тонку й рухливу грань? Організатори заходу запрошують усіх бажаючих Аолучитися Ао майбутніх Аискусій у стінах Національного юридичного університету імені Ярослава Мудрого і Національної акалемії правових наук України та на сторінках журналу «ілософія права і загамьна теорія права».

(C) Н. Сатохіна, 2020

ОАержано/Received 10.12.2020 